\title{
A LEITURA DO LITERÁRIO COMO PRÁTICA POLÍTICA
}

\author{
Paulo Venturelli*
}

A literatura faz os homens mais sensiveis e estimula sua imaginação. E homens com sensibilidade $e$ imaginąão são difficeis de se explorar, de se reprimir. Essa é a grande função da literatura: criar gente inconformada com a realidade. Mário Vargas Llosa

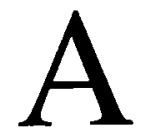

bordar mais uma vez a questão da leitura é tarefa espinhosa. O que já não foi pensado, dito e escrito sobre essa atividade? Se olharmos a produção crítica e analítica a respeito, o número de obras é espantoso. E encontraremos um paradoxo: por que há tanta gente preocupada com a leitura e desenvolvendo toda sorte de reflexão a seu respeito? Onde está a raiz do problema, considerandose que grande parte desses estudos está voltada para a difusão do ler? O problema é a suposição de que a leitura anda rarefeita entre nós, sendo ocupação de privilegiados. É moeda corrente: no Brasil, ninguém lê, basta ver o porte das edições - três mil exemplares. Assim, como explicar os milhões de volumes de Paulo Coelho que se multiplicam em edições sem fim? $\mathrm{E}$ os livros de Chico Buarque que têm tiragens altas, ultrapassando cem mil exemplares? E uma obra não digestiva como Tudo que é sólido desmancha no ar, de Marshall Berman, um estudo sobre a

* Universidade Federal do Paraná. 
modernidade? $O$ autor chegou a vir ao Brasil para saber por que o livro vendia tanto. Além disso, nos anos 70, foi lançada a coleção Os imortais da literatura universal. O primeiro volume, Os irmãos Karamázovi, de Dostoiévski, que não é romance de fruição de fim de semana, vendeu sessenta mil exemplares. E os livros do prolífico Jostein Gaarder, que não cessam de ser êxitos editoriais entre nós?

Estes tópicos apontam para a necessidade de uma reavaliação de certos conceitos. Cabe uma ponderação: nós - o mundo dos intelectuais - consideramonos leitores e estamos conscientes das transformações que esse exercício provocou em nossas vidas. Queremos que outros partilhem dessa ventura. Mas, se formos sinceros, dando rápida olhada para trás, para nossos tempos de jovens, o que encontramos? Quando cursamos o ginásio, o científico, a universidade, a maioria dos amigos, conhecidos e familiares lia continuamente? Ou éramos nós os alienígenas, curvados sob o peso de nossa aura? Se focalizarmos aquele tempo, veremos que a leitura não era ocupação popular. Nem por isso o mundo chegou ao juízo final. E existiria um país no mundo em que a maioria das pessoas dedica-se a tal exercício? Pensando em obras literárias, talvez sejamos obrigados a concordar com Enzensberger: "na verdade, ela (a literatura) sempre foi um tema para uma minoria. A quantidade dos que se dedicam a ela provavelmente se manteve constante no decorrer dos dois últimos séculos. O que mudou foi apenas a formação desse grupo. Já não é mais uma marca de privilégio de classe se interessar por ela, mas também não é mais uma obrigação de classe fazer isso.""

Antes de nos alongarmos em divagações, é necessário estabelecer alguns parâmetros. Em primeiro lugar, reafirmamos que leitura não é hábito, nem gosto. É prática e, como tal, está sujeita a uma série de variantes:

a) a social - para a leitura desenvolver-se, o Brasil precisaria ter um projeto em que livro e cultura fossem plantados como valores fundamentais, de identidade do indivíduo e do grupo. Isto ocorre? Num país como o nosso, em que dirigentes políticos apregoam a modernidade, quando a maioria das classes populares não dispõe do mínimo para sobreviver, vivendo em situação de feudo medieval, que importância pode ter um livro?

b) a familiar - quantas famílias, no Brasil, dispõem de biblioteca razoável em casa, em cujo clima a criança crescesse, aprendendo que ler é fundamental? Por falar em biblioteca, quantas cidades e bairros possuem

1 ENZENSBERGER, H. M. Elogio ao analfabetismo. In: Mediocridade e loucura e outros ensaios. São Paulo: Ática, 1995, p. 53. 
uma? Por outro lado, o jovem que lê é estigmatizado: um gênio, o que equivale a dizer: é oriundo das transcendências, longe dos comuns mortais; ou então: é um desajustado, seria mais saudável ir para a rua, socializar-se com seus amigos, namorar, ler tanto faz mal; ${ }^{2}$

c) a escolar - como a escola trata o venturoso e lúdico exercício de leitura? Quase nunca como venturoso, nem lúdico. Muito menos como exercício. É obrigação burocratizada. Não passa de mais uma tarefa enfadonha como tantas, sem ligação com a vida do aluno. A escola tornou a leitura algo fossilizado. Sem preparar o aluno para o discurso literário, joga nas mãos deste uma obra que não será lida e sim, no máximo, mal decodificada, para o enfrentamento de um teste. A leitura perdeu o teor significativo. Ler não é mais produzir significado, entrar no texto para reescrevê-lo e por meio dele captar as sondas que o autor lançou sobre dores e alegrias humanas. Literatura, na escola, é questão de enredo e personagem, título e característica. É vista como se os autores tivessem uma fórmula mágica, a qual se submeteriam para produzir o texto. Linguagem, visão de mundo, diálogo com a tradição e com as outras produções não são levados em conta.

Recuperemos as palavras de Leyla Perrone-Moisés: "o que eu proponho ou defendo é que possa existir o espaço de uma literatura com um projeto maior do que o de simples consumo. Que esse espaço seja garantido pelos editores e que, no ensino, os alunos possam ter acesso a essa literatura considerada mais difícil, mais árdua, que exige mais conhecimento para ser lida." ${ }^{3} \mathrm{E}$ isso requer trabalho redobrado de preparação. $O$ grande entrave para o desenvolvimento dessa prática na escola é o professor. Quem de nós efetivamente lê dentro de uma perspectiva interacionista, vendo o livro não como um objeto isolado, escrito por um autor em momentos de inspiração ou em decorrência de sua genialidade, mas como uma resposta a muitos outros textos, criando uma teia de referências que só um ato profundo de leitura consegue flagrar, para a obra ser melhor entendida?

2 Sobre os propalados malefícios da leitura Cf. ZILBERMAN, R. Fim do livro, fim dos leitores? São Paulo: Editora Senac, 2001, especialmente o capítulo "Ler faz mal?", p. 39-56.

3 PERRONE-MOISÉS, L. Literatura contra a barbárie. Folha de São Paulo, 2 ago. 1998. Mais, p. 4. 
Talvez Pedro Demo tenha razão quando escreve: "fabrica-se a ignorância, o analfabetismo político, a imbecilização popular. [...] A miséria do aluno é no fundo a mesma do professor, não só mal pago, mas igualmente incompetente formal e politicamente." Esta questão estendida para a área cultural mostra a dramaticidade com que nos deparamos ao analisar a leitura;

d) a pessoal - podemos ainda encontrar um nó difícil de deslindar: ler para quê? ler por quê? ler o quê? Vivemos numa sociedade imediatista, tudo tem que dar resultado já. $O$ discurso neoliberal que nos ataca, coloca na mente e nos corações que o importante da vida é o bem material, o dinheiro.

Em nosso país, governo, empresários, banqueiros, artistas, jogadores, apresentadores de tevê garantem polpudos salários, concentrando privilégios tidos como direitos. Dentro dessa arcada, que sentido tem aqui ler? Anestesiados pelo fetiche do consumo, enfronhamo-nos nas lojas e procuramos conter o vazio que nos assola. Vivemos esquecidos de um projeto cultural para a vida, projeto esse que nos dê norte e sul que se projetem para além do raso sobreviver cotidiano. O quadro desolador que vemos pelas esquinas não é produto da natureza, nem desígnio dos deuses. Foi composto por nossa história, por nós e por aqueles que insistem em deixar o Brasil como um lugar periférico.

Dessa forma, a criança e o jovem, crescendo cercados por valores constituídos de pragmatismo, podem vir um dia a valorizar a leitura como um lento processo de enriquecimento mental, para o alargamento de sua visão e de sua crítica? Seus louros ídolos televisivos, seus ídolos do futebol são analfabetizados, lustrados pelos dólares e pela mídia a serviço do discurso neoliberal que vê neles exemplos a ser seguidos. Não por acaso, uma campanha do governo para a vacina infantil, veiculada nos meios de comunicação, perguntava: já pensou se os pais deste garoto não o tivessem vacinado? E aparecia um desportista popular. O que está implícito aí? Ele ganha muito dinheiro, é milionário - logo, é o modelo para nossos filhos. Sendo assim, torna-se até muito cômodo olhar para os jovens e dizer: eles não querem nada com nada. Antes, deveríamos perguntar: em que mundo eles nasceram? como foram educados? que ensinamentos receberam? Ler é uma prática de vida em que é necessário pesar esses pontos.

4 DEMO, P. Cidadania menor: algumas indicaçōes quantitativas de nossa pobreza política. Petrópolis: Vozes, 1992. p. 24-25. 
Nesta reflexão, nosso pensamento está em tomo da leitura do literário. Isso não descarta outros tipos de texto, pelo contrário, como esperamos deixar claro na definição de literatura a seguir. Aí está em jogo uma série de valores e carga ideológica que nos molda em nossas atitudes. Importante é abandonar posturas mecanicistas ou voluntaristas que, perpetuando o modelo atual, continuarão sacrificando gerações de brasileiros.

Entendemos literatura do ponto de vista de Antonio Gómez-Moriana:

\begin{abstract}
...literatura é uma confrontação dialética de discursos, quando estes são ironizados, parodiados e, inclusive, subvertidos, sendo que tais operações são as mais importantes que a literatura vem realizando há muito tempo e sob diferentes formas. Todo este trabalho ocorre sobre os usos da linguagem que sempre são regulados socialmente. Rompendo as fronteiras das formulações discursivas que se querem pertencentes com exclusividade aos diferentes campos do saber, a literatura examina os discursos produzidos nestes e por estes campos e, ao contrastá-los, oferece uma visão plural da sociedade que os gera e os sustenta. ${ }^{5}$
\end{abstract}

Chamamos a atenção para o ponto importante: a subversão de discursos praticada pela literatura. Isso nos remete a algo complexo: literatura não é cantiga de ninar para embalar o leitor em seus gostos, em suas expectativas. Bem salientou Diogo Mainardi: "literatura não provoca identificação, mas estranheza. Não pode confirmar o que o leitor já sabe. Não pode dignificar o seu cotidiano. Deve contestálo."6 Ou seja, a literatura vem nos sacudir de nosso conformismo. Quem se dispõe a isso? Num tempo dominado pela idéia do hedonismo, quem tem energia para revirar seus princípios pelo avesso e ver se procedem? Talvez aqui esteja a primeira razão para a rala popularidade do texto literário. Ler é trabalho que se introjeta nos usos da linguagem, regulados socialmente: até nosso padrão lingüístico é questionado com a leitura. Seremos forçados a perceber que não existe uma única língua portuguesa, a culta ou a padrão. Ela é um corpo ilimitado de propostas para serem articuladas pelos falantes, segundo sua necessidade, classe social, interesses etc.

5 GÓMEZ-MORIANA, A. A açāo e o tempo em El Burlador de Sevilla. In: RIBEIRO, R. J. A sedução e suas máscaras: ensaios sobre Don Juan. São Paulo: Companhia das Letras, 1988. p. 42.

6 Diogo Mainardi. Anotaçōes de arquivo. 
Nosso centralismo lingüístico, fruto de nosso centralismo político, esboroa-se ante as evidências: não há o português certo e o português errado. E justo o praticado pelas classes populares será crivado como erro, desvio. A literatura também nos tira do eixo sob este aspecto.

Outro detalhe: o literário rompe as fronteiras dos discursos. Por meio do trabalho dialógico, para a literatura não há mais a história, a psicologia, o jornalismo etc., como campos autônomos. É de seu caráter passear por estes gêneros discursivos e provocar brechas em nosso ilusório muro de certezas. Como diz Terry Eagleton: "a literatura, no sentido que herdamos da palavra, é uma ideologia. Ela guarda as relações mais estreitas com questões do poder social." E, ainda: "não existe uma "essência' da literatura." Eis por que podemos asseverar que nenhum texto é literário em si mesmo, como se o autor tivesse o condão de arrolar diamantes em lugar de palavras. O estatuto artístico será estabelecido pelos discursos criados em torno da obra, na interação conflitiva e inacabada de leituras. E para encerrar este aspecto: a literatura propõe visão plural da sociedade - campo minado de diversos, contraditórios naipes de ser e existir. Visão plural significa ir além da linearidade estabelecida entre o certo e o errado, o normal e o anormal. Ainda a mesma pergunta: quem está disposto a abandonar categorias estabelecidas e partir para a aventura da convivência com o diferente? com aquilo que nos causa espanto e angústia? com o que consideramos oposto a nossas crenças? Eis a radicalidade da literatura. Não por acaso ela exige iniciados em suas filigranas, com longo preparo. Não estamos defendendo o elitismo: a literatura para entendidos. Não, é apenas um alerta para quanto trabalho temos pela frente, se efetivamente estivermos empenhados em difundir a prática do ler como atitude transformadora e não apenas um apanágio acadêmico de nossas rotinas escolares. E isso inclui revisão urgente do fosso arbitrário entre a alta literatura e os produtos da cultura popular.

Além dessas facetas apenas tangenciadas, é bom lembrar que a literatura lida com outro tempo. Nossa sociedade é pragmática, utilitarista, sôfrega por resultados que requeiram o menor esforço. A tecnologia da informática é louvada pela enorme economia de tempo que nos oferece. Perguntamos: para quê? Para ocuparmo-nos com leitura? É sintomático que, nesta sociedade, um filme, a resolver nós intrincados ou não em duas horas, tenha muito mais penetração que o livro, que requer dez, vinte dias para ser desbaratado. Se o tempo físico de leitura exige maior

p. 30 .

7 EAGLeton, T. Teoria da literatura: uma introdução. São Paulo: Martins Fontes, 1997.

8 Ibid., p. 12. 
largueza, o tempo da maturação dos signos em nossa mente deve ser ainda maior. É preciso fazer concatenações, avançar e recuar, paralisar a leitura para fruir certos elementos, mergulhar nas camadas constitutivas como quem enfrenta labirinto muito diverso da estrada reta e pavimentada em que tentamos construir nosso vaivém. Sem esquecer, igualmente, de auscultar as vozes nem sempre nítidas que ali, nas entrelinhas do texto, estão inscritas.

Ou seja: ler não é apenas desfrutar do enredo, pois requer o mapeamento das variadas línguas com que o texto estabelece relações e, ao mesmo tempo, como tais relações se instituem no trabalho pessoal do autor lido. Ler por este empenho é participar da obra, mas não apenas na concepção insuficiente de obra aberta. É dela participar para refazer nossa própria arquitetura pessoal, uma vez que a natureza do texto, segundo Michel Schneider, é feita de fragmentos originais, montagens singulares, referências, acidentes, reminiscências, empréstimos voluntários. No mesmo diapasão, "de que é feita uma pessoa? Migalhas de identificação, imagens incorporadas, traços de caráter assimilados, tudo (se é que podemos dizer assim) formando uma ficção que se chama o eu."9 Nessas circunstâncias, ao enfrentarmos um livro, estamos vivendo ficções em convergências e compreender a nós próprios como ficção não é exercício que acalme angústias, porque abre fissuras numa superfície que pensávamos e queríamos una e inteiriça. $E$, no embalo de hoje, quando somos abalroados pelo fascismo do consumo ${ }^{10}$ e retalhados pelo genocídio cultural, ${ }^{11}$ quem se aventura por essas regiōes de tanto desafio? Correr por vitrines e telas, investir-se do roteiro do flâneur, numa sequiência temporal em que as cenas nos transpassam na velocidade da luz, acaba por nos anestesiar. E como Pangloss, aceitamos que este é mesmo o melhor dos mundos, cabendo-nos apenas ir em frente, fruindo as miragens do mercado.

Seria pertinente resgatar a visão de Pasolini que, pensando a realidade do seu país, levantou uma série de chaves que são coerentes com a situação vivida pelos brasileiros. Suas posturas nos podem orientar nesse emaranhado de conceitos e atitudes da modernidade. Diz ele: "detesto tudo o que é relativo ao consumo, eu o abomino no sentido físico do termo [...] A antipatia que sinto em meu foro íntimo é tão insuportável que não consigo fixar os olhos, por mais de alguns instantes, numa tela de televisão. É um fato físico, me dá náusea. Aliás toda a cultura de consumo

9 SCHNEIDER, M. Ladrões de palavras: ensaio sobre o plágio, a psicanálise e o pensamento. Campinas: Editora da Unicamp, 1990. p. 15.

10 LAHUD, M. A vida clara: linguagem e realidade segundo Pasolini. São Paulo: Companhia das Letras, 1993. p. 23.

11 lbid., p. 33. 
me é intolerável, sem apelação."12 Ele estava muito atento ao que chamava de neocapitalismo. Para o escritor, as formas que a sociedade vem tomando são ditadas pela burguesia que apaga esse fato, fazendo tudo passar como a condição humana. Assim, se alguém é miserável, isto não se dá porque do outro lado há alguém que acumulou riquezas. A miséria faria parte da realidade do ser, traço ontológico de triste sina. Por meio da industrialização, a cultura do hedonismo e do consumo da burguesia passou a se espalhar para as classes populares com eficiência, porque conta com a tecnologia para fazer a difusão. Dessa forma, as classes trabalhadoras são contaminadas. Suas manifestações culturais, que poderiam ser autêntica oposição à cultura burguesa, são diluídas ou exterminadas. Esse fato Pasolini entende como genocídio: destrói o pluralismo, tragado pela sonda da cultura monolítica de massa. Pasolini também irá acusar tais mecanismos como forma de poder fascista. Esclarece como esses fatores irão incidir de forma trágica sobre o corpo e a alma das pessoas, ocasionando mutação antropológica.

Aqui no Brasil, a professora Nilda Ferreira, em seu estudo sobre a cidadania, vai passar por arcada semelhante à de Pasolini, quando diz: "em lugar de um povo de cidadãos, assiste-se ao surgimento de uma massa de consumidores, para quem o que importa é poder usufruir individualmente dos resultados das conquistas da ciência e da técnica."’3

E Pasolini vai mais adiante. A tragédia da sociedade de massa, de consumo, desemboca num problema que, trazendo seu raciocínio para a nossa questão, pode esclarecer a possível apatia do público pela leitura: os jovens são homogeneizados, diluídos numa situação histórica que os obriga a viver "a própria infelicidade sem que nada possa fazê-los vir a tomar consciência dela". ${ }^{14}$ Talvez, as hordas de jovens cruzando nossas ruas, as gangues nos centros e nas periferias, as torcidas organizadas de futebol que dão vazão ao ímpeto de morte, tenham nesses fatos uma raiz que nos permite aclarar seu status de vandalismo urbano. Há grande vazio que precisa ser preenchido. Falta-lhes projeto de vida em que possam de verdade ser o homo sapiens com que somos classificados. Presos à engrenagem que lhes tira a capacidade de encontrar identidade pessoal e comunitária, não dispõem de meios para construir o cotidiano dentro de perspectiva de futuro. ${ }^{15} \mathrm{E}$ isso afunila-se para a velha polêmica

12 PASOLINI, P. P. Apud LAHUD, op. cit., p. 33.

13 FERREIRA, N. T. Cidadania: uma questāo para a educação. Rio de Janeiro: Nova Fronteira, 1993. p. 183.

14 PASOLINI, P. P. Apud LAHUD, op. cit., p. 110.

15 Quanto a esta questão, gostaríamos de trazer, para ilustrá-la, experiência recente que tivemos numa escola de periferia. Conversando sobre o valor/necessidade da leitura com alunos da sétima 
da reificação do homem: nosso corpo, nossa mente reduzidos a simples coisa exposta a uma situação de exploração, como Marx já alertara. Os jovens, nós todos, estamos impossibilitados de ler nossas vidas, e quem não é leitor de si mesmo e do que está em torno, não tem meios para tornar-se leitor de livros.

E entra em cena outro personagem desta história. Nossa sociedade, especialmente a escola, é pródiga em alimentar mistificações. É comum encontrarmos afirmações acerca do escritor $\mathrm{X}, \mathrm{Y}$, ou $\mathrm{Z}$ que seria um gênio, que teria o dom de escrever, que receberia em certos momentos a inspiração. Claro, se o mundo é capitalista, valoriza assim, o capital, não o trabalho. Gênio, dom, inspiração seriam os capitais invisíveis que os grandes recebem. Essa invisibilidade é estratégica: não revela, na riqueza e no luxo de alguns que vivem bem, o trabalho do operário. $\mathrm{O}$ mesmo se transporta para a literatura, dificilmente vista como trabalho. Essa é mais uma forma das ideologias hegemônicas justificarem as classes sociais: o autor é um gênio inspirado, leitor, enquanto você, não passa de pobre miserável. Sua única saída é aceitar esta posição. Você não tem o dom, não é capaz de criar. E a história da leitura do próprio autor, seu duro aprendizado, quantas vezes ele fez e refez o mesmo texto até chegar àquele resultado que conhecemos, tudo isso é escamoteado, camuflando-se o empenho dos autores em meio aos brilhos do talento natural. Georges Snyders enfatiza como "é um consolo, um incentivo saber que, sobretudo para os maiores, o caminho não foi suave". Ele mesmo defende a necessidade dos recomeços, de novos encontros, e circunstâncias, de certo distanciamento para que a luz da cultura realmente se faça presente. ${ }^{16}$ Lembremos de Guimarães Rosa: "Genialidade, sei... Eu diria: trabalho, trabalho e trabalho". ${ }^{17} \mathrm{E}$ de outro trabalhador

série, num determinado momento, um garoto pediu a palavra e disse, taxativamente: "Tudo isso que o senhor tá falando é bonito, mas não vale nada, porque pra nós não tem mais futuro." Se um adolescente tem esta visão, obviamente ela foi criada numa série de circunstâncias. Ele aprendeu a dura tragédia de não haver perspectivas pela frente. E já não tem nada a perder. Juntar-se em gangue para encontrar resquício de identidade e sentido é o caminho mais curto para o menino ser logo anulado pelo sistema de valores que legou à sua geração a impossibilidade de ser. Reverter esse quadro, incutindo nele a autoestima e, principalmente, modos de libertação por meio da arte seria a tarefa pedagógico-política mais desafiadora e humana que a escola deveria fazer. Está equipada humana e culturalmente para isso? $\mathrm{Ou}$ prefere reprovar, expulsar esse tipo de gente de seus quadros? E continuar pregando que literatura é coisa de gênio, dom de poucos, deixando de lado o resgate que poderia ser feito com aluno com essas marcas, desde que the fosse permitido descobrir que também é criador, tem algo a dizer, seu discurso precisa ser ouvido, transformando sua energia autodestrutiva em impulso para a ampliação de horizontes nos quais ele tenha inseção como recriador de si e do mundo?

16 SNYDERS, G. Alunos felizes: reflexão sobre a alegria na escola a partir de textos literários. Rio de Janeiro: Paz e Terra, 1993. p. 107.

17 Apontamentos de arquivo inéditos de Guimarāes Rosa. 
VENTURELLI, P. A leitura do literário como prática...

da palavra que muito nos pode ensinar na remodelação das tarefas na escola, Henry Miller: "Não inventamos nada, na verdade. Pedimos emprestado e recriamos"18.

A dimensão humana da criação, a amplitude de vida que poderia proporcionar aos alunos o caminho de existência produtiva, desde que aprendessem a recriar o seu dia-a-dia, ficam sufocadas por preconceitos elitistas, a colocar o artista num pedestal, para que sejamos forçados a esquecer o que seríamos se condições favoráveis estivessem em nosso caminho. $O$ grande pecado das pedagogias que se aplicam por aí têm sua sustentação neste terreno. Fazendo uso outra vez de palavras de Enzensberger: "foi o analfabeto que inventou a literatura. Suas formas elementares, do mito à canção de ninar, do conto de fadas ao canto, da oração à charada, são todas mais antigas que a escrita. Sem a transmissão oral não existiria a poesia, e sem os analfabetos não haveria livros." ${ }^{19}$ Talvez, com esses pressupostos em mente, possamos humanizar o trabalho com os alunos e recuperar um pouco o lastro histórico que estamos jogando na lata de lixo, por falsidade ideológica de nossa forma de atuar. Noutros termos: para levarmos a leitura à escola como dimensão vital, cada professor poderia, antes de indicar uma obra, fazer um passeio pela vida do autor, conhecendo detalhes de seu exercício criativo, aproximando-se do empenho diário e da luta mefistofélica com a palavra, com a história sendo muitas vezes criada em pedaços, de modo obscuro, sem um ponto de partida e de chegada muito evidente. Um professor, como leitor, ensinando leitura com eficácia, precisaria começar a ensinar aos alunos que o livro não é escrito num repente, num passe de mágica, com páginas que vêm prontas das alturas. $O$ escritor não é o médium que se senta na mesa para psicografar em jato único a obra que se derrama de cântaros celestiais. Recuperar o dia-a-dia da carpintaria textual, talvez seja o primeiro passo para humanizar a leitura, desescolarizando- $a$, inserindo-a numa área de aprendizagem vivencial e acessível ao aluno. E, para tanto, levar os autores até os alunos tem sido um laboratório rico para ambas as partes, até por que, descobrir que o escritor não é um semideus, mas alguém da mesma cidade, do mesmo bairro, sujeito a contrariedades comuns, aproxima as pessoas. E quebra a barreira ideológica da mistificação com que discursos prontos querem cimentar a distância entre autor e leitor. Na troca de experiências e papéis, o leitor iniciante, em pouco tempo, chegaria ao patamar mais desejável: ele não precisa restringir-se ao mero consumo de livros. Ele também tem algo a dizer.

18 MILLER, H. Epílogo. In: . O sorriso ao pé da escada. Rio de Janeiro: Salamandra, 1979. p. 45.

19 ENZENSBERGER, op. cit., p. 44. 
A literatura, fruto do diálogo de discursos, entraria em nossas vidas como convite para explorarmos um campo em que as significações não estão fechadas. Por meio dessa interação constante, cada um de nós atualizaria o que Sófocles escreveu há séculos: "há muitas maravilhas, mas nenhuma é tão maravilhosa quanto o homem". ${ }^{20} \mathrm{O}$ dom, nós já temos. É a vida. A tarefa mais difícil está bem realizada: aprendemos uma língua. A partir daí, é trabalho, trabalho, trabalho, leitura contínua e significativa, nova arquitetura para os sentidos e os afetos, com poros abertos a múltiplos influxos. Assim será possível falar em humanidade e, especialmente, em humanismo. Assim ler vale a pena, porque recria a vida e nos impulsiona a recriála em qualquer texto desfrutado.

Até aqui, levantamos panorama desalentador e concordamos com Tomaz $\mathrm{T}$. da Silva, quando reflete sobre a hegemonia do pensamento neoliberal: "ele não apenas coloca novas questöes, introduz novos conceitos; ele, sobretudo, desloca e reprime outras categorias, obscurece a memória popular, ocupa o lugar de categorias que moveram nossas lutas no passado, redefinidas agora como anacrônicas e ultrapassadas". O educador continua em sua reflexão:

...o discurso da qualidade total, das excelências da livre iniciativa, da modernização, dos malefícios da administração pública reprime e desloca o discurso da igualdade/desigualdade, da justiça/injustiça, da participação política numa esfera pública de discussāo e decisão, tornando quase impossível pensar numa sociedade e numa comunidade que transcendem os imperativos do mercado e do capital. ${ }^{21}$

Nesta história de que o mundo mudou, de que as categorias do pensamento social estão velhas, tenta-se processar um passe de mágica: anular as contingências que brotam de certas estruturas políticas e econômicas a causar os rasgos do tecido que compõe nossa realidade. $O$ Brasil como país subdesenvolvido não oferece essa condição por estar nos trópicos ou por decorrência da miscigenação e de nossa incompetência. Há profunda história de exploração e corrupção nos bastidores. Não podemos descartar as relações estreitas entre o desenvolvimento do Primeiro Mundo e o atraso em que patinamos. Não é fato que nossa economia seja resultado do

20 SÓFOCLES. Antígona. In: . A trilogia tebana. Rio de Janeiro: Jorge Zahar, 1990. p. 210.

21 SILVA, T. T. Idensidades terminais: as transformaçōes na política da pedagogia e na pedagogia da política. Petrópolis: Vozes, 1996. p. 110. 
VENTURELLI, P. A leitura do literário como prática...

colonialismo passado e do atual? Ou, o pagamento mutilante de nossas dívidas não confirma ainda mais a privatização da riqueza, concentrada em mãos de poucos, enquanto a educação, a saúde, os serviços sociais estão sendo dilapidados por interesses que desejam a perpetuação do sistema, pois assim mais lucros são usufruídos?

Pensar que estes fatores são apenas questão de gerenciamento público, que empresários e banqueiros, unidos a certos políticos, vão dar ao país o desejável perfil democrático é camuflar as articulações que esses personagens movem em interesses próprios (com as exceções alentadoras, é claro), sem medir as consequiências de seus jogos para a comunidade. A ganância, a crueldade e a concentração estão aí, basta ter olhos para vê-las. Se estamos voltando nosso pensamento para a leitura, esta é a postura mais urgente: recuperar nossas preocupações sociais, nossas práticas de mobilização e militância. Pensar dentro dessas balizas não é retrógrado nem maniqueísta. Anular nossas conquistas e fazer de conta que é natural aquilo que é vivenciado a partir de decisões políticas de grupos, não garante a estatura de modernidade. O que se difunde pelos meios de comunicação é ideologia de conveniência a eliminar certas responsabilidades, como fica evidente nas oscilações do mercado (o sobe e desce da moeda, por exemplo), feitas em nome de interesses e da manutenção da riqueza num circuito estreito.

Apesar disso, o Brasil tem dado exemplos de resistência. Esta é visível em nossa produção literária. Muitos autores novos surgem, novas editoras e livrarias são criadas. Em termos de cultura mais ampla, há inegável multiplicação de veículos que não apenas divulgam os caminhos que vão sendo seguidos na produção artística, como discutem os rumos do país e suas diversas faces. $O$ surgimento, ainda que pontual, do mundo hip-hop e suas linguagens anima as cores do cenário, com a diversidade se fazendo ouvir. Por trás dessas configurações, crescem os leitores e as formas de ler. As bienais do livro, os congressos que ocorrem de sul a norte servem de diagnóstico da situação. Se nossa educação é lamentável, justo em nome disso estamos desenvolvendo massa crítica considerável que, além de análise e reflexão, aponta saídas concretas para os impasses. E, restringindo-nos ao nosso campo, publicações como Cadernos de literatura brasileira, Bravo!, Cult, Inimigo Rumor, Palavra, entre muitas, são comprovações vigorosas do movimento em aberto das artes.

É claro que, num cenário neoliberal, não podemos esquecer que "não se trata apenas de denunciar as distorções e falsidades" desse pensamento, "tarefa de uma crítica tradicional da ideologia (ainda válida e necessária), mas de identificar e tornar visível o processo pelo qual o discurso" com estas características "produz e cria uma 'realidade' que acaba por tornar impossivel pensar e nominar uma outra 
'realidade"'.22 Ainda assim, há sintomas de que, mesmo com a política de terraarrasada que vem sendo perpetrada por recentes grupos que chegaram ao poder, malhas de grandezas se estendem por nosso país, e isso aparece em recente pesquisa. Perguntados se pudessem falar com Deus, o que pediriam, jovens de 12 a 20 anos mostraram interesse em ajudar a comunidade. Mais da metade não se debruçou sobre problemas pessoais. ${ }^{23}$

Isso é alentador, quando o individualismo é estimulado e "as lutas por grandes ideais transformaram-se em luta por consumo." ${ }^{24}$ Lutar por uma causa que abranja a coletividade é saída racional para o genocídio em que estamos envolvidos. Lembremos: "a consciência dos fins que orientam sua atividade coloca o homem diante da possibilidade de identificar em outros homens os seus próprios propósitos, colocando-os todos em condições de comunhão, no melhor sentido." $\mathrm{E}$ ainda: "a vinculação a uma causa orienta a destinação do homem, conferindo significado à sua existência e fazendo com que supere sua solidão errante no mundo, pois com ele estão também outros homens." 25

A miríade de organizações voltadas para o amparo e a solidariedade (o que não se confunde com assistencialismo ou com assumir tarefas que deveriam ser do Estado, uma vez que tais organizações também enfatizam à conscientização política) tem merecido destaque justamente no campo educacional: artistas, intelectuais, escritores das mais diversas estirpes, desportistas estão descobrindo que, quebrando o casulo, há lá fora um mundo de gente sedenta por aprender. E aprendem. Uma gota consoladora neste oceano a comprovar nossa posição: Yo-Yo Ma, tido como o maior violoncelista na atualidade, dedica parte de seu tempo para ensinar música, ao redor do mundo, a crianças desassistidas. Filho de chineses, ele nasceu em Paris e é naturalizado americano. Pesquisador incansável, as linhas que se trançam em sua cidadania, também perfazem seu trabalho. De olho na tradição popular, ele busca a pigmentação folclórica que há em Schumann, em De Falla, em Piazzolla, em Villa-Lobos. Mr. Ma, como é chamado, fascina-se por combinar o clássico e o popular, facilitando o acesso à arte a um maior número de pessoas. E já que corre o mundo ensinando seu ofício, diz que nunca encontrou uma criança incapaz de aprender. Está aí um mote que poderíamos transpor para nossas salas de aula, em especial quando tratamos de literatura.

22 SILVA, op. cit., p. 104.

23 DIMENSTEIN, G. Virgens, Deus e os safados. Folha de São Paulo, 6 set. 1996. Cotidiano, p. 10.

24 FERREIRA, op. cit., p. 183.

25 Ibid. p. 6. 
É mais do que tempo de ultrapassarmos a visão naturalista de Adam Smith. Segundo ele, basta a concorrência, e a riqueza de cada um seria fruto de sua inteligência e de seu esforço, como se o homem vivesse isolado, independente da sociedade. O meio sócio-econômico é decisivo para as soluções de vida do sujeito, inclusive para a assunção dessa condição. $\hat{E}$ ali que ele encontra a seiva de formação da personalidade e visão de mundo, no que avulta a educação. Nesta é compreendida a leitura, com o desenvolvimento que acarreta, permitindo a cada um tornar-se outro e atingir a "força centrípeta do "nós" que "está na identificação de cada um com o todo e na percepção de ser mais do que si mesmo". ${ }^{26}$ Para quem franze o cenho, vendo nisso a utopia, trazemos a palavra de Sérgio P. Rouanet: "uma utopia é aquilo cujo valor político, cuja produtividade histórica está justamente em ser apenas um telos. Mas pode-se, evidentemente, extrair, de uma utopia, um programa político[...], utopia que, como todo sonho, nega o existente e aponta para uma realidade diferente."27

A professora Nilda T. Ferreira dá-nos quadro dramático de hoje:

...encapsulado em si mesmo, o homem já não se interessa em saber quem é, de onde veio ou para onde vai. Busca prazer, não deveres. Sua vida se reduz a uma aventura psicológica, na qual vive experiências isoladas. Não se sente culpado por nada. Vive bem no mundo das aparências[...], flutua entre ilusão e desilusão, que não chegam a ser uma desgraça, pois no mundo do descartável tudo se troca. Para ele, ver não remete a conhecer, mas a seduzir. Que lhe importam a civitas, a lei, o espaço público, se só se satisfaz individualmente, na própria intimidade? [...] quebra-se em mil pedaços por não poder satisfazer o maior dos seus desejos, possuir-se a si mesmo.[...] Não pensa mais em conhecer a própria identidade, satisfaz-se com a idéia de que, vivendo bem, não importa quem é ou será. ${ }^{28}$

Mesmo com essa perspectiva, não podemos cair no imobilismo fatalista para o qual nos alertou Paulo Freire. Como educadores, professores, pais, podemos assumir a postura militante apregoada por Pasolini. Precisamos aprender a ensinar

26 FERREIRA, op. cit., p. 171.

27 ROUANET, S. P.; MAFFESOLI, M. Moderno e pós-moderno. Rio de Janeiro: UERJ/Departamento Cultural, 1994. p. 68.

28 FERREIRA, op. cit., p. 197. 
a olhar os movimentos populares com generosidade. Em lugar de encontrar neles espírito de anarquia ou de bagunça, conforme estampou em sua capa a revista Veja, perceber ali a revelação do povo como entidade histórica, em busca de direitos. Se nada temos a fazer junto desses movimentos, que pelo menos não atrapalhemos, difundindo preconceitos e distorções, no interesse da mídia que tem atrás de si colonizadores de nossas mentes. Ser leitor é ter olhos abertos para interpretar o real e não aceitar a interpretação de outrem, interessado em camuflar as relações de fatos nunca isolados. Para nos manter nas trilhas do pensamento de Nilda T. Ferreira: "a educação para a cidadania precisaria empenhar-se em expurgar de cada homem as crenças, as fantasias, as ilusões [...] que em nada contribuem para o desenvolvimento de uma consciência crítica. Sob esse enfoque, a ingenuidade, para não dizer a ignorância, é profundamente negativa, já que a pessoa ingênua é facilmente enganada pelos detentores do poder." 29

Por este viés, colocamos nosso discurso na defesa da razão. E razão como sistema de pensamento e ações que não é repressivo no sentido de anular ou desvalorizar o emocional. Pelo contrário, conjuga esses constituintes do ser humano visto como um todo, ainda que incompleto. Pesando deste ângulo, o mundo racional é aquele que ajuda a perceber que pertencemos a um universo maior, onde não podem prevalecer apenas desejos e intenções subjetivas. Nós convivemos, nossa consciência é com-ciência: percepção de que estamos inseridos num contexto de ininterrupta interação e com o outro podemos lograr atingir uma totalidade. A leitura, como via de conhecimento, localiza-se neste entrecruzamento. É instrumentação que nos livra das malhas egocêntricas e propicia acesso ao mundo como realidade não de conformismos e sim de lutas constantes, em nome de um vir-a-ser que se dá na busca da utopia. Sem esta e

...sem um sonho coletivo, uma sociedade estagna sobre os louros de suas conquistas. Ou regride ou se deixa dominar pelos padrões de outras mais fortes [...]. A utopia é aquele conjunto de projeções, de imagens, de valores e de grandes motivações que inspiram práticas novas e conferem sentido às lutas e aos sacrifícios para aperfeiçoar a sociedade. Pela utopia se procura sempre ver para além da realidade dada. ${ }^{30}$

29 FERREIRA, op. cit., p. 221.

30 BOFF, L. O despertar da águia: o dia-bólico e o sim-bólico na construção da realidade. Petrópolis: Vozes, 1998. p. 96. 
Utopia, convém lembrar, vem do grego: $u$-topos, o que está fora do lugar. Está fora do lugar hoje, pode estar no lugar amanhã. Assim aprendemos com Sônia Kramer: "resistência ética, nascida da certeza de que embora vivendo na selva somos humanos e, portanto, devemos impedir que a dimensão animal de nossa condição de espécie se sobreponha à dimensão humana de nossa condição de ser social." Está definido nessas palavras um programa de defesa da racionalidade que, instalada em nosso horizonte, norteararia nossas buscas de cidadãos leitores.

A desmistificação de valores repressivos e castradores como gênio, dom natural e a abertura de possibilidades criativas a todos passa por esses suportes. $\mathrm{Na}$ linguagem, encontramos a instância que define o ser humano. É pertinente que entendamos o fato que seria óbvio, não fossem nossas práticas privilegiadoras de cânones instituídos como verdade. Afinal, "sem o domínio lingüístico, sem a lógica comunicativa e participatória não se constrói a coesão social, nem a criatividade de sentidos do mundo, nem as intervenções que modificam o meio ambiente", segundo Leonardo Boff; e ainda: "é a partir da linguagem que os seres humanos elaboram a reflexão, a consciência e o eu. Por ela eles constróem o mundo como rede de significados e como habitat com regularidades e com dinamismos que o fazem adaptar-se e eco-evoluir continuamente". ${ }^{32}$

Ora, literatura é linguagem. Sua dialogia intensa explora infindas possibilidades. Nossa mente, em constante tensão/interação com ela, abre-se para um mundo de criações significativas que não são privilégios de uns poucos, tendo em vista que a língua é de todos. Por esses meios, será possível ascender ao ponto de seres produtores de sentido, o que nos livraria de sermos fantoches passivos como insiste em nos limitar a realidade do consumo. Todavia, o que é ser criativo? Para fugir do facilitário do idealismo, usamos as palavras de Dimenstein quando reflete sobre os caminhos da educação: "idiotizar o aprendizado é obrigar a memorização de regras, numa era de abundância de informações. Idiotizar é estimular o aluno a ir bem nos testes, em vez de envolvê-lo na experimentação para que desenvolva a paixão pela curiosidade. É não mostrar como as várias disciplinas se relacionam, aplicadas ao cotidiano". E o jornalista prossegue, enfatizando a necessidade do aluno/ser humano aprender a ser "alguém disposto a inovar, rompendo sempre os parâmetros". ${ }^{33}$

Aqui desponta o claro espectro do que é criatividade: ir além dos parâmetros. $\mathrm{Na}$ escola, na família, na sociedade, fazemos o oposto. Para nós, o bom, o certo, o

31 KRAMER, S. Por entre pedras: arma e sonho na escola. São Paulo: Ática, 1993, p. 162.

32 BOFF, op. cit., p. 85.

33 DIMENSTEIN, G. Como fazer de seu filho um idiota. Folha de São Paulo, 5 jul. 1998. Cotidiano, p. 5. 
adequado, é o jovem, o aluno adaptar-se ao existente. Não por acaso, vivemos cortando, castrando as novas gerações. Somos Procusto reatualizado. Estamos, pois, induzindo, não educando. Educar para a criatividade e leitura, mais que mera retórica, É propiciar elementos para que os seres experimentem modulações outras para tudo, em amplos sentidos. A literatura é excepcional para sensibilizar-nos para tal tarefa. Os autores dignos desse nome estão sempre experimentando, não se submetendo ao conquistado e definido, procurando ir um passo além. Isso rompe a programação que visualiza o mundo como sequêencia já prevista. Rubem Alves diz: "a nossa humanidade é uma invenção. Não existe uma natureza humana, no sentido de uma essência biológica fixa. Nós nos tornamos humanos trilhando os caminhos que as culturas estabeleceram." 34 Ora, se somos capazes de nos inventar e reinventar, que este trabalho seja voltado para o prazer de ser alguém de luzes e formas passíveis de remodelação, sem nos submeter aos protótipos de arte, literatura, leitor codificados pela mesmice escolar, dentro de pedagogia conservadora que apregoa a criação como tarefa de eleitos. Via leitura, podemos estabelecer curtos-circuitos que implodirão as amarras, e viver será, de fato, muito perigoso, porém, estaremos articulando e desarticulando estruturas. Em nossa carne, carregaremos a nebulosa que é tensão conflitante e princípio de novos mundos: "antes navegar, livre, nos mares da incerteza, na esperança de horizontes, que habitar, seguro, nos charcos onde o naufrágio é impossível..." 35

Naufragar é preciso, porque do fundo do mar traremos material para composições inovadoras. E se morrermos nesta aventura, nossos despojos servirão de diretrizes aos que vêm depois. Teremos morrido, só que antes navegamos pelo oceano do pensamento e da criação e conhecemos as maravilhas que alguns queriam destinados apenas aos eleitos. E tais colocações têm consequiências drásticas. Em termos de cidadania, "não se trata de formar cidadãos que pensem poder resolver sozinhos os problemas, mas pessoas que percebam o quanto precisam caminhar junto com outras, aprender a negociar seus conflitos, ganhar e seduzir seu companheiro para projetos que atendam aos anseios coletivos". ${ }^{36} \mathrm{O}$ que isto significa em termos de mundo político, econômico, social, não pode escapar de nossas vistas: precisamos atingir a base do capitalismo: a idéia e a prática da propriedade privada dos meios de produção, principal agente de desmandos do mundo e, em especial, do conhecimento mantido, por fórmulas elitistas, nas mãos daqueles raros que a ele têm acesso. Eis o desafio: rediscutir a posse do dinheiro, da terra, da máquina, da

34 ALVES, R. Variaçōes sobre a vida e a morte. São Paulo: Paulinas, 1992. p. 75.

35 ALVES, op. cit., p. 127.

36 FERREIRA, op. cit., p. 228. 
VENTURELLI, P. A leitura do literário como prática...

educação e das letras, se quisermos encontrar saída racional para os absurdos contemporâneos.

Por isso, ser cidadão, ser leitor criativo, atuar de forma concreta na organização da sociedade impele-nos a desestabilizar a ordem instituída, reagindo às formas autoritárias e repressivas da política, da economia e da cultura, buscando soluções para os problemas de nossa comunidade e não nos atrelando a eles como se viessem de forças transcendentais. E, para tanto, o livro é um meio de esclarecimento e de convite à participação. Contra a impotência, a consciência ativa, racionalmente trançada, dinamizada pelo conhecimento na leitura, é caminho de reconstrução de nossas buscas. Tal empenho utópico deve nortear-nos toda vez que abrimos um livro. Ele não é apenas divertimento e evasão. É uma lição de fazeres, suas páginas contêm direções e com nossa faculdade de análise e abstração desenvolvida entenderemos melhor nossos contextos. Concebendo outros modelos de sociedade, seremos capazes "de pensar retrospectiva e prospectivamente", encontrando "na memória do passado a matriz de antecipação do futuro, isto é, o presente é uma vivência plástica, maleável, habitada pelo futuro que depende de nós". ${ }^{37}$ Em termos concretos, precisamos superar nossas posturas céticas e desesperadas, compreendendo que as certezas são provisórias e sujeitas a novas configurações, contudo, ainda são capazes de nortear nossos passos. É esta, sem dúvida, a atitude de um leitor, de um homem no mundo, de um homem de letras no Brasil.

Terry Eagleton faz a seguinte reflexão: "há razões concretas para se duvidar que a educação tenha o poder transformador[...] Afinal de contas, ela é parte da sociedade, e não uma solução para esta; e quem, como perguntou Marx, educaria os educadores?"38 O pessimismo é razoável, se a educação continuar praticada com pressupostos conservadores, quando não passa de preparação de mão de obra para o onipresente mercado. Ainda que o emprego seja fundamental, não podemos perder de vista a possibilidade de uma educação libertária, voltada para a racionalidade e a motivação participativa do educando, tornando-o leitor consciente e não ingênuo. É necessário resgatar o princípio educativo como a dialética continuidade/ruptura, sabendo que educar "não se reduz a um desenvolvimento do que já estava latente, a uma simples aquiescência às forças espontâneas do ser". ${ }^{39}$ É notório como as classes governantes jogam com a ignorância e a desinformação das pessoas. Por isso, a luta para se colocar um livro nas mãos de maior contingente é subversiva e

37 ROUANET, S. P. Reinventando a utopia. In: As razões do lluminismo. São Paulo: Companhia das Letras, 1987. p. 327.

38 EAGLETON, op. cit., p. 46.

39 SNYDERS, op. cit., p. 162. 
inconformista, por que "o escritor sente mais intensamente que os outros a comunidade humana - e é por isso que ele sente com tanta freqüência a necessidade de se dirigir a ela, e evocá-la como capaz de existir em sua multiplicidade unida" ${ }^{40}$ Tal fato não quer dizer que o escritor tenha um aparato de sensibilidade especial in natura. A referida capacidade de sentir mais intensamente vem de sua prática de leitura contínua, forja do ver/sentir/produzir, porque nela adquire elementos para ir/ver mais longe. Em razão disso pode transmitir uma decodificação do real que nos levaria a mudar as práticas de vida. Sendo assim, estaríamos abrindo brechas e aí está embutida a tarefa fundamental: a superação do nível subjetivo de gestos pessoais e a contínua emanação "de hábitos com os quais já estamos familiarizados, buscando-se sempre um nivel de cultura mais elaborada", ${ }^{41}$ no sentido de ver como pensamento e criação ocorrem em rede.

Esta é a práxis essencial para o leitor. Claro que tudo isso é incômodo, exigindo constantes esforços de todos, no sentido de não se perder o rumo, porque "cultura é conscientização e por isso mesmo exacerbação de conflitos e dores. A partir do momento em que me tira do 'banho morno', ela me obriga a confessar as angústias e as discórdias que existem dentro de mim, ela me coloca diante da miséria e da vergonha dos homens". ${ }^{42}$ E só um cidadão movido por esta dinâmica pode ter sensibilidade e disposição para se empenhar por um mundo concretamente melhor e não ficar apenas embalado por sonhos idealistas, sem meios para efetivá-los. Não devemos descartar os livros em nome do pragmatismo cotidiano, e sim buscar neles modos de nos refinar para vida mais perceptiva e afetos concretizados em relações de troca ininterrupta. Para ninguém o caminho é fácil. Cada ato assim direcionado requer aquele sentimento de Victor Hugo, quando dirigiu-se ao seu professor: sem $o$ senhor, eu teria crescido pequeno. ${ }^{43}$

Dentro desta ótica, a escola tem função primordial: mostrar que "a cultura de 'massa' não é produção inevitável da sociedade 'industrial', mas fruto de uma forma particular de industrialismo que organiza a produção visando ao lucro e não ao uso; que se preocupa com o que vender, e não com o que é valioso". ${ }^{44} \mathrm{E}$, nesse encaminhamento, frisamos que, apesar de nossa sociedade o negar, na vida é muito mais importante a cooperação do que a competição, que nos transforma em seres violentos, adversários, quando poderíamos ser fraternos. A luta a se travar inclui a

40 SNYDERS, op. cit. p. 152.

41 Ibid., p. 39.

42 SNIDERS, op. cit., p. 43.

43 HUGO, apud SNYDERS, op. cit., p. 179.

44 EAGLETON, op. cit., p. 46. 
VENTURELLI, P. A leitura do literário como prática...

resistência aos mecanismos sociais que tentam nos sujeitar, nos integrar em algo homogêneo, sem forma definida. Como dizia Pasolini, é preciso não ceder, não sucumbir à irracionalidade, mas fazer uso do único meio que apresenta eficácia: "a força da razão com a coerência e a resistência física e moral que ela confere". ${ }^{45} \mathrm{Em}$ nome deste desafio, procuramos o perfil do que sentimos ser crucial na reflexão sobre leitura. Nossa postura norteia-se pelo desejo de fugir do monologismo. Nele seríamos presa do beco-sem-saída da não-alternativa. Esperamos com esta visada plural ganhar fôlego para, ao menos, indicar algum encaminhamento mais sólido às nossas lides educativas. Queremos reafirmar um aspecto que é a base do que foi abordado: a utopia. Temos em mente a utopia vista em linguagem poética por Eduardo Galeano: "Ela está no horizonte [...] Aproximo-me dois passos. Caminho dez passos, ela se afasta dois passos. Caminho dez passos e o horizonte fica dez passos mais longe. Por muito que eu caminhe, nunca a alcançarei. Para que serve a utopia? Serve para isto: para caminhar."46

Claro que, como educadores radicais, não estamos em busca de uma verdade já cristalizada e pronta para nossos moldes. Sabemos que "a verdade nunca é independente da leitura e das práticas de escrita que utilizamos para chegar a ela e pronunciá-la." 47 E é justo por isso que insistimos na renovação galileana da leitura em sala de aula. Mudar a prática: ler não mais de forma obrigatória, ler não mais um livro por turma, ler não em decorrência de decisão que o professor tomou; transformar a sala de aula num mostruário de linguagens do mundo e orientar o aluno a partir de nossas múltiplas leituras e dos interesses daquele, realizando a confluência fluida de falas multidirecionadas. Caminhos assim traçados permitirão ao educando se aproximar de uma prática de discurso lido e escrito que lhe desvele universos como jogo de interesses. E, pronunciando a sua palavra recheada pelo que leu/viveu, terá em mãos os meios para atuar nestes jogos de cena e conhecer quais são as práticas envolvidas naquilo que lhe é imposto como verdade, como saber, como competência. No resultado dialético dessas linhas cruzadas, ele descobrirá que sua própria subjetividade é processo em construção e que ele, aluno, não está de antemão condenado ao fracasso, conforme o pronunciamento daquele adolescente antes mencionado. Ou, nos termos de Peter MacLaren: "os estudantes precisam aprender a ler não como um processo de submissão à autoridade do texto, mas como um

45 PASOLINI, apud LAHUD, op. cit., p. 25.

46 GALEANO, apud CANDAU, V. et al. Oficinas pedagógicas de direitos humanos. Petrópolis: Vozes, 1995. p. 5.

47 MAcLAREN, P. Multiculturalismo revolucionário: pedagogia do dissenso para o novo milênio. Porto Alegre: Artes Médicas, 2000. p. 31. 
processo dialético de compreensão, de crítica e de transformação". ${ }^{48}$ Transformação em especial do próprio conceito de leitura não mais como via passiva de consumo do que está pronto na página, mas como fruição que, a partir da página, incentive o aluno a entrar no labirinto sem fim das possibilidades de se recriar e recriar o mundo concreto à sua volta.

Sem dúvida, ao chegar ao fim deste artigo, o leitor pode estar com a sensação de ter sido, uma vez mais, envolto em nuvens evanescentes. Estamos firmemente estribados no discurso. Nem poderia ser diferente. Mas se o leitor deixar-se iludir, pensando que, no fim das contas, tudo não passa de apenas discurso, gostaríamos de finalizar nossa reflexão com as palavras de MacLaren: "qual é o papel do educador universitário? As palavras são ferramentas revolucionárias quando elas criticam sistemas de pensamento, não sendo apenas outras palavras. É verdade que as palavras não chegam às ruas, mas quando usadas para criticar e transcender estruturas de dominação, elas podem servir como veículos da práxis libertadora." ${ }^{\prime 9} \mathrm{E}$ os fatos talvez comecem a simplificar-se se deixarmos de colocar em sala de aula o livro como um fetiche apaziguador e enganoso, acreditando que nos basta adotá-lo para os problemas, desigualdades, barreiras, insuficiências serem magicamente resolvidos. O livro é só o começo. É uma zona de luta. É o espaço em que se confrangem variegadas vozes sociais que o aluno precisa aprender a decompor, juntando sua voz à voz do professor e à do autor. Um livro é relação com centenas de outros, sendo, portanto, ação e criação. E sua presença em sala só faz sentido como impulso para outras criações. E criar é perguntar, porque a pergunta move o mundo, não a resposta. Domesticados, nossos alunos são levados sempre a responder e, pela resposta, são avaliados. Resposta é fechamento. Pergunta é abertura: como foi que eu me tornei o que o mundo fez de mim? - coloca-nos MacLaren. Neste passo, começamos a nos ler, para depois ler o mundo escrito. E, se nosso artigo apresenta um envolvimento visceral, excessivamente enfático, isso ocorre porque tentamos seguir os passos de Gramsci: não tratar os problemas de forma apenas profissional e acadêmica. Não é possível continuar marcando passo na crença de que o Brasil é o país do futuro. Nossos alunos são realidades do presente. Se este não for modificado, aquele futuro dificilmente deixará de ser sombrio.

48 Ibid., p. 38.

49 MAcLAREN, op. cit., p. 109. 


\section{RESUMO}

Propomos a leitura como prática sujeita a variantes sociais, familiares, escolares e pessoais. O que é ler no país da ignorância? Os jovens crescem cercados por valores pragmáticos. Literatura é rede de linguagens, subverte discursos, não embala o leitor. Contestando seu cotidiano, abala o centralismo linguístico, rompe fronteiras de discursos. $O$ estatuto artístico depende de flutuações discursivas. $O$ texto dialógico se abre para contradições sociais, instigando-nos à convivência com diferenças. Ler é lidar com outro tempo, superar a sofreguidão imediatista: exige lenta maturação de signos, concatenação de camadas de referências. Literatura é montagem singular e coloca em cheque a ficção do $e u$. Sob o fascismo do consumo, o neocapitalismo esvazia o sentido da vida. Este genocídio cria massa de consumidores, não cidadãos. Isto gera violências. A escola permanece na mistificação: escrever é obra de gênios. O trabalho do escritor desaparece. Precisamos re-humanizar o sentido do ler. O estudante pode descobrir no ato da leitura um modo de recriar-se. $O$ pensamento neoliberal obscurece a história das lutas sociais. Ler é recuperar estas trilhas. A literatura brasileira mostra resistência. Na precariedade educacional temos gerado massa crítica respeitável. Cresce a perspectiva contra o individualismo, pois ler abre para o coletivo, forma compromisso, supera crendices. Da perspectiva interacionista, ler quebra parâmetros, desestabiliza ordens instituídas, abre o espírito à cooperação, não à competição. Tem sentido utópico: verdades e subjetividades são processos em devir. A escola precisa estar alerta à não submissão ao texto: ler é fruir, impulso para transcender estruturas castradoras. Livro não é fetiche. É zona de luta.

Palavras-chaves: Leitura literária, interacionismo, educação e cidadania.

\section{ABSTRACT}

We conceive reading as a practice subject to social, familiar, educational and personal variables. What does it mean to read in the land of ignorance? Youngsters grow up amidst pragmatic values. Literature is a net of languages: it subverts discourses rather than comforting the reader. Confronting everyday life, literature rocks linguistic centralism and breaks discourse frontiers. The artistic status depends on discursive drifting. The dialogical text opens up to social contradictions, inviting us to live with differences. To read is to deal with another time, going beyond immediate cravings: it requires slow ripening of signs, the linking of many layers of references. Literature is a singular assembling which questions the fiction of the self. Under the tyranny of consumerism, neocapitalism deprives life of meaning. This genocide creates a mass of consumers, not citizens, and this generates violence. The school maintains the mystification: writing is for geniuses. The author's work disappears. We must re-humanize the meaning of reading. 
The student can find in reading a way to recreate the self. The neoliberal thought obscures the history of social struggles. Reading is finding the lost trails. Brazilian literature displays resistance. The educational frailty breeds considerable critical mass. The antiindividualistic perspective blooms, since reading opens up to common interests, gives shape to commitment, overcomes superstition. From an interactionist perspective, reading causes parameters to be broken, established orders to be shaken, opening up the minds to cooperation, not to competition. It has, thus, a utopic sense: truths and subjectivity are always in the making. The school needs to be alert, so as not to submit to the text: to read is to enjoy, it is an impulse towards the transcendental. Books are no fetishes: they are battlefields.

Key-words: Literary reading, interactionism, education and citizenship.

\section{REFERÊNCIAS}

ALVES, R. Variaçōes sobre a vida e a morte. São Paulo: Paulinas, 1992.

BOFF, L.O despertar da águia: o dia-bólico e o sim-bólico na construção da realidade. Petrópolis: Vozes, 1998.

DEMO, P. Cidadania menor: Algumas indicações quantitativas de nossa pobreza política. Petrópolis: Vozes, 1992.

DIMENSTEIN, G. Como fazer de seu filho um idiota. Folha de S. Paulo, 5 jul. 1998. Cotidiano, p. 5 .

Virgens, Deus e os safados. Folha de S. Paulo, 6 set. 1998. Cotidiano, p. 10.

EAGLETON, T. Teoria da literatura: uma introdução. São Paulo: Martins Fontes, 1997.

ENZENSBERGER, H. M. Elogio do analfabetismo. In: Mediocridade e loucura e outros ensaios. São Paulo: Ática, 1995.

FERREIRA, N. T. Cidadania: uma questão para a educação. Rio de Janeiro: Nova Fronteira, 1993.

GÓMEZ-MORIANA, A. A ação e o tempo em El Burlador de Sevilla. In: RIBEIRO, R. J. A sedução e suas máscaras: ensaios sobre Don Juan. São Paulo: Cia. das Letras, 1988.

KRAMER, S. Por entre pedras: arma e sonho na escola. São Paulo: Ática, 1993.

LAHUD, M. A vida clara: linguagens e realidade segundo Pasolini. Sāo Paulo: Cia. das Letras, 1993.

MACLAREN, P. Multiculturalismo revolucionário: pedagogia do dissenso para o novo milênio. Porto Alegre: Artes Médicas, 2000. 
VENTURELLI, P. A leitura do literário como prática...

MILLER, H. O sorriso ao pé da escada. Rio de Janeiro: Salamandra, 1979.

PERRONE-MOISÉS, L. Literatura contra a barbárie. Folha de S. Paulo, 2 ago. 1998. Mais!, p. 4. ROUANET, S. P. Reinventando as humanidades. In: As razōes do lluminismo. São Paulo: Cia. das Letras, 1987.

ROVANET, S. P.; MAFFESOLI, M. Moderno e pós-moderno. Rio de Janeiro: UERJ/Departamento Cultural, 1994.

SCHNEIDER, M. Ladrōes de palavras: ensaio sobre o plágio, a psicanálise e o pensamento. Campinas: Editora da Unicamp, 1990.

SILVA, T. T. Identidades terminais: as transformaçōes na política da pedagogia e na pedagogia da política. Petrópolis: Vozes, 1996.

SÓFOCLES. Antigona. In: . A trilogia tebana. Rio de Janeiro: Zahar, 1990.

SNYDERS, G. Alunos felizes: reflexão sobre a alegria na escola a partir de textos literários. Rio de Janeiro: Paz e Terra, 1993.

ZILBERMAN, R. Fim do livro, fim dos leitores? São Paulo: Ed. Senac, 2001. 